\title{
New record of twig blight on Catharanthus roseus in India
}

\author{
Pankaj Sharma*, P. D. Meena and Y. P. Singh \\ Directorate of Rapeseed-Mustard Research (ICAR), Bharatpur 321 303, India.
}

Accepted 26 August, 2013

\begin{abstract}
During post rainy season 2011, twig blight disease symptoms were observed on Catharanthus roseus. Symptoms appeared as dark brown to black girdling lesions on the twigs. Acervuli containing masses of spores and dark setae were observed within lesions. On the basis of fungal morphology and completion of Koch's postulates, the pathogen was identified as Colletotrichum gloeosporioides (Penz.) Penz.\& Sacc.
\end{abstract}

Key words: Twig blight, Catharanthus roseus, Colletotrichum gloeosporioides

\section{INTRODUCTION}

Periwinkle or Vinca [Catharanthus roseus (Linn.) G.Don. syn. Vinca rosea Linn.] belongs to the family Apocynaceae. It is an erect highly branched lactiferous perennial herb which is a chief source of patented cancer and hypotensive drugs. Flowers are borne on axils in pairs. It is one of the very few medicinal plants which have a long history of uses. C. roseus has more than 400 known alkaloids in its different parts. The alkaloids like antineoplastindimeric, vinblastin and vincristine are mainly present in aerial parts, whereas ajmalcine, vinceine, vincamine, raubasin and reserpine are present in roots and basal stem. The dimericindole alkaloids from C.roseus are mainly used for treatment of various human cancers. Pharmaceutical industry use it for the treatment of childhood leukemia, Hodgkin's disease, testicular cancer and cancerous tumors. C. roseus is one of the very few medicinal plants which have a long history of uses as diuretic, antidysenteric, hemorrhagic and antiseptic agent. It is known for use in the treatment of diabetes in Jamaica and India. Prevention of cancer, cancer treatment, anti-diabetic, stomachic, reduces high blood pressure, externally against nose bleeding, sore throat and mouth ulcers (Graf et al., 1996; Kirtikar and Basu, 1993; Narayana and Dimri, 1990).

After post-rainy season, an estimated $65-80 \%$ of the $C$. roseus surveyed in Bharatpur and Jaipur, India, were infected with twig blight. Symptoms first appeared as dark brown to black girdling lesions on the twigs. When lesions occurred at the ground line, the entire runner died. Where healthy twigs touched the soil or infected plant parts, new lesions were developed. Within a few weeks, the disease was spread to stems and leaves and caused large sections of the bed to die (Figure 1). As long as cool, damp conditions remain, the disease spreads in the planting. The spores of the fungus disseminate primarily by splashing and flowing water. Acervuli containing masses of spores and dark setae were observed within lesions.

\section{MATERIALS AND METHODS}

Collection of disease samples and isolation

Diseased samples were collected from $C$. roseus plants in different localities in Bharatpur $\left(77^{\circ} 27^{\prime} \mathrm{E}, 27^{\circ} 12^{\prime} \mathrm{N}, 178.13 \mathrm{MASL}\right)$ and brought to the laboratory for isolations. Infected tissues were cut into small (approximately $5 \mathrm{~mm}^{2}$ ) pieces with sterilized scalpel and surface sterilized for $20 \mathrm{~s}$ in $95 \%$ ethanol followed by $60 \mathrm{~s}$ in $0.525 \% \mathrm{NaOCl}$. These tissues were washed thrice with sterilized distilled water and aseptically transferred onto $2 \%(\mathrm{w} / \mathrm{v})$ autoclaved potato dextrose agar (PDA; Merck, Germany) containing 50 mg/l 


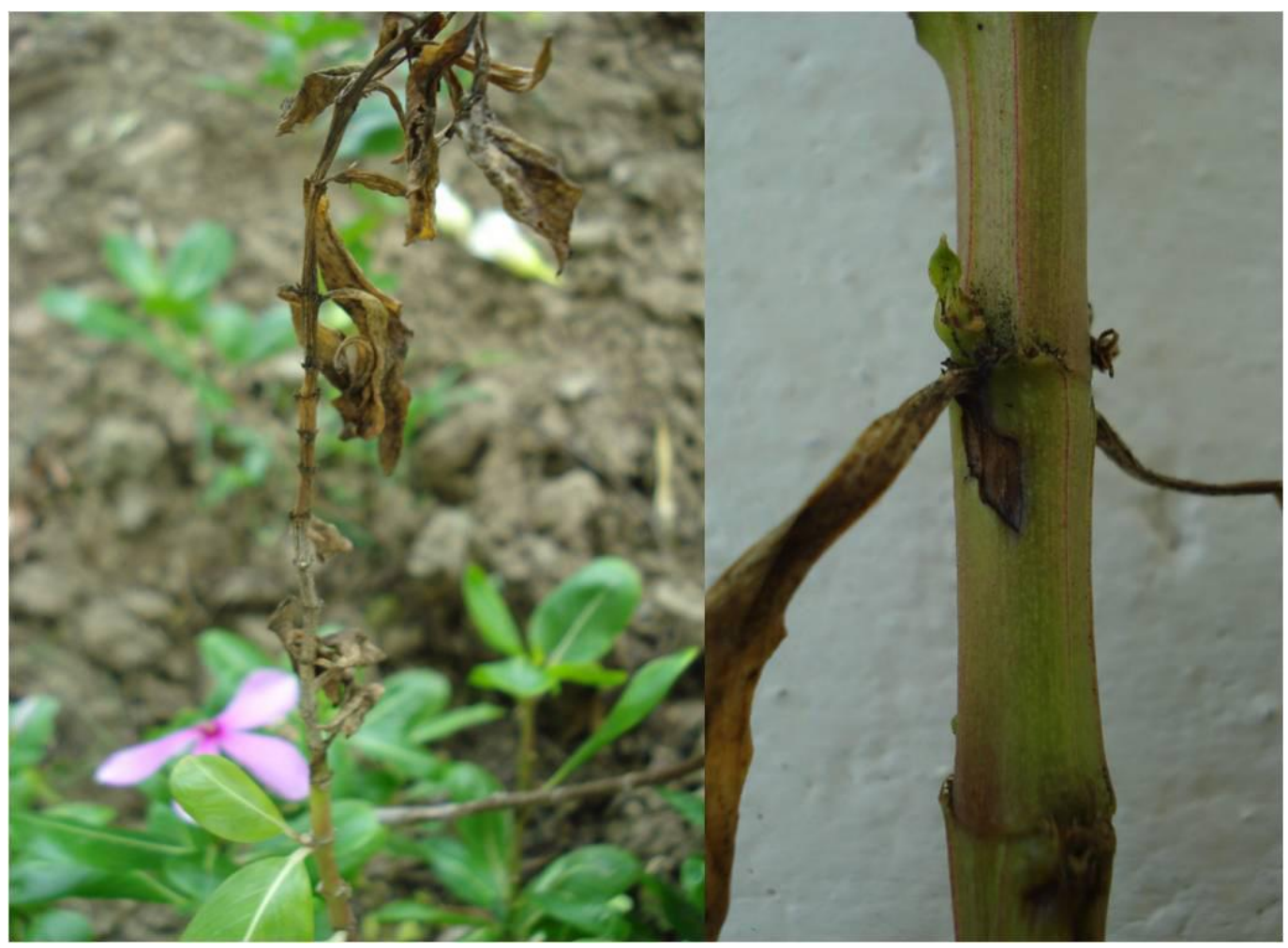

Figure 1. Stem blight symptoms on Catharanthus roseus.

streptomycin sulphate (Sigma, St. Louis, USA) medium in Petri plates. Inoculated Petri plates were incubated in the BOD at $25 \pm$ $2^{\circ} \mathrm{C}$ for seven days in the dark (Sharma et al., 2011a). Microscopic examination was conducted by mounting fungal tissue in water and lactophenol, and dimensions of 50 each conidia and conidiophores were measured from 7 days old cultures with the help of Pro-image analyser attached with light microscope (Olympus, Japan BX 51).

\section{Pathogenicity test}

Pathogenicity was tested by completion of Koch's postulates (Sharma et al., 2012a, 2013). Conidia obtained from 7-day-old PDA culture were suspended in sterile distilled water (SDW) to $10^{4}$ conidia $/ \mathrm{ml}$. 20 plants (45-days old) were sprayed with conidial suspension (50 $\mathrm{ml}$ on each) until runoff with hand sprayer. Plants were covered with plastic bags for $48 \mathrm{~h}$ and kept at $24 \pm 2{ }^{\circ} \mathrm{C}$. After 7 days, lesions were developed on inoculated leaves. The fungus was re-isolated from acervuli that developed on the twigs and leaves, following previously outlined procedures. Inoculation tests were repeated once. The control plants sprayed with SDW did not show any symptoms. The morphological and cultural characteristics of the re-isolated pathogen were compared with the original pathogen. The fungus was identified from all infected twig samples.

\section{RESULTS AND DISCUSSION}

Developing colonies were extremely variable, effuse, grey to brown and reverse dark brown. The teleomorph was observed as small black dots (perithecia) immersed in the centers of older colonies (more than 35 days old).
Conidia were borne on elongated phialides in acervular conidiomata. Conidia were straight, one-celled, hyaline, oblong, or cylindrical, slightly curved with truncate base and rounded apex and measured 15.0 to $22.5 \times 3.0$ to $5.5 \mu \mathrm{m}$ in size. These morphological characteristics of the isolate were consistent with the description of $C$. gloeosporioides (Penz.) Penz. \& Sacc. (Cannon et al., 2008). The Fungal Identification Service, Mycology and Plant Pathology Group, Agharkar Research Institute, Pune, India (Accession No. NFCCI 2650) confirmed the identity.

Leaf spots and stem lesions on common periwinkle caused by $C$. gloeosporioides were reported by Koelsch et al. (1995). However, twig blight of C. roseus was also earlier reported to be caused by Colletotrichum dematium (Pers.) Grove. (McMillan and Graves, 1996). C. gloeosporioides, causing leaf blight on many plants has been reported from India (Jamaluddin et al., 2004). The pathogen causes anthracnose on Saraca asoca (Sharma et al., 2011b) Jasminum grandiflorum (Sharma et al., 2012b), onion (Sikirou et al., 2011) and olive (Ali et al., 2010). C. gloeosporioides also causes banana fruit rot (Jat et al., 2013). This is the new record of $C$. gloeosporioides causing twig blight of $C$. roseus as per the literature cited in India (Bilgrami et al., 1991; Jamaluddin et al., 2004). Since C. roseus foliage is a good medicinal value plant, the disease damaging its foliage deserves special attention. 


\section{REFERENCES}

Ali R, Triki MA, Msallem M (2010). First report of olive anthracnose caused by Colletotrichum gloeosporioides in Tunisia. Phytopathol. Mediterr. 49:95-98.

Bilgrami KS, Jamaluddin, Rizawi MA (1991). Fungi of India List and References. Today's and Tomorrow's Printers and Publisher, New Delhi, $798 \mathrm{p}$.

Cannon PF, Buddie AG, Bridge PD (2008). The typification of Colletotrichum gloeosporioides. Mycotaxon 104:189-204.

Graf WD, Chance PF, Lensch MW, Eng LJ, Lipe HP, Bird TD (1996). Severe vincristine neuropathy in Charcot-M arie-Tooth disease type 1A. Cancer 77:1356-1362.

Jamaluddin M, Goswami MG, Ojha BM (2004). Fungi of India. Scientific Publishers, Jodhpur, pp. 37-38.

Jat BL, Sharma P, Gour HN (2013). Production of enzymes and toxins by Colletotrichum gloeosporioides Penz. causing banana fruit rot. Proc. Nat. Acad. Sci. India 83: 177-180. (DOI: 10.1007/s40011-0120125-y).

Kirtikar KR, Basu BD (1993). Indian Medicinal Plants Allahabad, India. 2nd Ed, 2:1523.

Koelsch MC, Cole JC, von Broembsen SL (1995). First report of leaf spots and stem lesions on common periwinkle caused by Colletotrichum gloeosporioides. PI. Dis. 79:83.

McMillan RT, Graves WR (1996). Periwinkle twig blight caused by Colletotrichum dematium on Catharanthus roseus L. Proc. Fla. State Hort. Soc. 109:1996.
Narayana MR, Dimri BP (1990). Periwinkle and its cultivation in India. Bulletin Central Institute of Medicinal and Aromatic Plants (India). 8:12.

Sharma P, Rai PK, Siddiqui SA, Chauhan JS (2011a). First report of Fusarium wilt in the broomrape parasite growing on Brassica spp. in India. PI. Dis. 95:75.

Sharma P, Singh N, Verma OP (2011b). First report of anthracnose caused by Colletotrichum gloeosporioides in Saraca asoca. J. Mycol. PI. Pathol. 41:464-465.

Sharma P, Singh N, Verma OP (2012a). First Report of Curvularia leaf spot, caused by Curvularia affinis on Dalbergia sissoo. Forest Pathol. 42:265-266.[ DOI:10.1111/j.1439-0329.2011.00745.x]

Sharma P, Singh N, Verma OP (2012b). First report of Colletotrichum gloesporiodes on Jasminum grandiflorum in India. J. PI. Prot. Res. 52:91-92.

Sharma P, Meena PD, Chauhan JS (2013). A new host for Nigrospora oryzae (Berk. \& Broome) Petch causing stem blight on Brassica juncea from India. J. Phytopath. 161:439-441. (DOI: 10.1111/jph.12081).

Sikirou R, Beed F, Hotègni J, Winter S, Assogba-Komlan F, Reeder R, Miller SA (2011). First report of anthracnose caused by Colletotrichum gloeosporioides on onion (Allium cepa) in Benin. New Dis. Reports. 23:7 [doi.10.5197/j.2044-0588.2011.023.007]. 